\title{
PERATURAN MENTERI SOSIAL REPUBLIK INDONESIA NO 3 TH 2018 TENTANG BIMBINGAN, PENGAWASAN, DAN PELAPORAN PELAKSANAAN PENGANGKATAN ANAK SEBAGAI PERLINDUNGAN HUKUM TERHADAP HAK ANAK ANGKAT
}

Ahmad Royani, S.H.,M.H.

Fakultas Hukum, Universitas Islam Lamongan

royanilaw@gmail.com

\begin{abstract}
ABSTRAK
Bahwa untuk melaksanakan ketentuan Pasal 42 Peraturan Pemerintah Nomor 54 Tahun 2007 tentang Pelaksanaan Pengangkatan Anak, perlu menetapkan Peraturan Menteri Sosial tentang Bimbingan, Pengawasan, dan Pelaporan Pelaksanaan Pengangkatan Anak. Pengangkatan anak harus dilakukan berdasarkan peraturan yang berlaku, proses pengangkatan anak harus melalui penetapan Pengadilan hal ini sesuai dengan ketentuan dalam Peraturan Pemerintah nomor 54 tahun 2007. Pengangkatan anak yang dilakukan tanpa penetapan pengadilan dapat menimbulkan akibat hukum yang merugikan baik bagi anak angkat maupun orangtua angkatnya. Akibat-akibat hukum yang dapat timbul seperti misalnya, terganggunya hubungan anak angkat dengan anggota keluarga lain dalam hal pewarisan ataupun hak-hak dan kewajiban masing-masing seperti yang telah diatur didalam perundangundangan. Dengan adanya penetapan pengadilan atas pengangkatan anak ini menjadikan anak angkat mendapat kepastian hukum yang sangat penting didalam statusnya sebagai anggota keluarga baru dalam lingkungan keluarga orangtua angkatnya.
\end{abstract}

Kata kunci : Pengangkatan Anak, Perlindungan Anak, Penetapan Pengadilan

\section{PENDAHULUAN}

Anak perlu mendapat perlindungan atas kepentingan hukumnya dalam memberikan jaminan terhadap pemenuhan hak haknya serta adanya perlakuan tanpa diskriminasi. berdasarkan undang undang No 35 tahun 2014 tentang perlindungan anak yang di maksud perlindungan anak adalah segala kegiatan untuk menjamin dan melindungi orang tua tersebut. Kemudian rela memberikan anaknya pada orang orang lain yang lebih mampu atau kepada yayasan untuk di didik dan di pelihara agar mendapat kesejahteraan seperti yang di harapkan.
Di lain pihak pasangan suami istri yang tidak dapat mempunyai anak sedangkan masyarakat umum masih beranggapan bahwa suatu keluarga belum lengkap bilamana belum di hasilkan keturunan dari perkawinannya sehingga wajar apabila sepasang suami istri senantiasa mendambakan kehadiran seorang anak dalam kehidupan rumah tangganya. Untuk dapat mewujudkan keinginan tersebut tak jarang para pasangan suami istri tersebut mengambil anak, baik dari anggota kelurganya maupun orang lain untuk di jadikan anak angkatnya.

Pada prakteknya pihak pihak yang melakukan pengangkatan anak bukan 
Jurnal Independent Fakultas Hukum

hanya pasangan suami istri saja tetapi ada pula yang di lakukan seorang yang tidak terkait dalam perkawinan yang sah atau orang yang belum menikah dan menurut SEMA No. 6 tahun 1983 tentang penyempurnaan pemeriksaan permohonan pengesahan atau pengangkatan anak. Pengangkatan anak yang demikian tersebut diperbolehkan.

Dalam pengangkatan anak ini demi kepentingan orang tua yang mengangkat dengan sejumlah motif yang ada di belakangnya dapat di penuhi dengan baik di satu pihak sedang di pihak lain kepentingan anak yang di angkat atas masa depanya yang lebih baik harus lebih terjamin kepastiannya.

Tujuan dari pengangkatan anak pada mulanya adalah untuk meneruskan keturunan mana kala di dalam suatu perkawinan tidak dapat diperoleh keturunan. Ini merupakan motivasi yang dapat di benarkan dan merupakan alternatif yang positif dan manusiawi terhadap naluri kehadiran seorang anak dalam pelukan keluarga.

Namun dalam seiring dengan perkembangan masyarakat sekarang ini menunjukkan bahwa tujuan dari pengangkatan anak tidak lagi semata mata

${ }^{1}$ Zaini Muderis, 1985, Adopsi suatu tinjauan dari tiga sistem hukum, bina aksara jakarta hlm 18 . atas motivasi untuk meneruskan keturunan saja, tetapi lebih beragam ke dari situ. ${ }^{1}$

Namun pada saat ini yang terpenting dalam pengangkatan anak ini adalah demi kepentingan kesejahteraan anak sebagaimana di nyatakan dalam (pasal 39 ayat (1) UU No. 35 tahun 2014) tentang perlindungan anak yaitu bahwa pengangkatan anak hanya dapat di lakukan untuk kepentingan yang terkait bagi anak dan di laksanakan berdasarkan adat kebiasaan setempat dan ketentuan peraturan perundang-undangan yang berlaku.

Kebutuhan akan pengangkatan anak dalam masyarakat kian hari kian bertambah sehingga dirasa perlu adanya jaminan kepastian hukum dalam pengangkatan anak di mana jaminan tersebut hanya bisa di dapat setelah memperoleh suatu putusan pengadilan, melalui putusan pengadilan tersebut di harapkan dapat diperoleh pedomanpedoman, petunjuk arah serta kepastian pada perkembangan lembaga pengangkatan anak dan hakim sebagai pihak yang memegang peranan penting yang akan menetapkan atau memutuskan di kabulkan atau permohonan pengangkatan anak yang di ajukan ke pengadilan tentunnya tidak akan bertindak gegabah karena hak ini 
Jurnal Independent Fakultas Hukum

sangat berpengaruh sekali terhadap kehidupan anak untuk masa yang akan datang. Karena yang di jadikan tujuan utama dalam pengangkatan anak adalah untuk kepentingan kesehjahtraan anak dalam menghadapi kasus kasus pengangkatan anak, perlu di perhatikan adalah dengan pengangkatan anak tersebut akan terjamin kehidupan perkembangan secara wajar dan kesejahteraan si anak tersebutlah yang hendaknya di jadikan pegangan dalam ${ }^{2}$

Mengingat di Indonesia belum mempunyai undang undang mengenai pengangkatan anak yang berlaku umum atau bersifat nasional, maka di Indonesia masih tedapat keaneragamaan dalam pengaturan pengangkatan anak. Di Indonesian terdapat tiga ketentuan hukum yang mengatur tentang pengangkatan anak, yaitu berdasarkan hukum berat yang di atur dalam stb 1917 nomer 129 yang berlaku bagi golongan tionghoa.

Oleh karena itu adanya perbedaan ketentuan yang mengatur masalah pengangkatan anak maka sering sekali timbul permasalahan yang berkaitan dengan setatus anak angkat dan akibat hukum dari pengangkat anak. Apabila kita cermati maka dari ketiga ketententuan hukum yang mengatur pengangkatan anak

\footnotetext{
${ }^{2}$ Ibid, hlm. 8

${ }^{3}$ Fauzan, Hukum Pengangkatan anak, Kencana,2008J,akarta, hlm. 44.
}

di Indonesian tersebut masing masing mempunyai perbedaan dalam hal setatus anak angkat dan akibat hukum pengangkatan anak terutama yang menyangkut tentang warisan.

Menurut Thamrin Nasution, orang tua merupakan setiap orang yang bertanggung jawab dalam suatu keluarga atau tugas rumah tangga yang dalam kehidupan sehari-hari disebut sebagai bapak dan ibu. Jika menurut Hurlock, orang tua merupakan orang dewasa yang membawa anak ke dewasa, terutama dalam masa perkembangan ${ }^{3}$ Tugas orang tua ialah melengkapi dan mempersiapkan anak menuju ke kedewasaan dengan memberikan bimbingan dan pengarahan yang dapat membantu anak dalam menjalani kehidupan. Dalam memberikan bimbingan dan pengarahan pada anak akan berbeda pada masing-masing orang tua kerena setiap keluarga memiliki kondisikondisi tertentu yang berbeda corak dan sifatnya antara keluarga yang satu dengan keluarga yang lain

\section{METODE PENELITIAN}

Tipe penelitian hukum yang di lakukan adalah yuridis normatif (hukum normatif). Metode penelitian hukum

4 M. Budiarto, S,H, 1991, Pengangkatan Anak Ditinjau dari segi hukum, Akapres, jakarta, hlm. 14 
Jurnal Independent Fakultas Hukum

normatif adalah suatu prosedur penelitia ilmia yang menemukan kebenaran berdasarkan logika keilmuan hukum dari sisi normatifnya ${ }^{5}$ Oleh karena itu penelitian hukum ini di fokuskan untuk mengkaji penelitian hukum tentang kaidah kaidah atau norma norma dalam hukum positif, yakni nirma hukum yang terkait dalam kedudukan anak angkat dan akibat hukum dari pengangkatan anak.

\section{HASIL PEMBAHASAN}

Hingga saat ini peraturan perundang-undangan yang secara khusus mengatur mengenai pengangkatan anak belum ada, sehingga belum ada pengangkatan yang pasti mengenai akibat hukum dari pelaksanaan pengangkatan anak. Berdasarkan wawancara terhadap hakim yang menangani pemohonan pengesahan pengangkatan anak, hakim menyatakan bahwa pengangkatan anak menimbulkan akibat hukum sebagai mana yang telah dirintis oleh pengadilan yang sebelumnya :

1. Kekuasaan orang tua Dengan disahkanya pengangkatan anak melalui penetapan pengadilan, maka kekuasaan orang tua tersebut berisi kewajiban untuk mendidikdan memelihara anaknya.

${ }^{5}$ Jhony ibrahim, teori dan metode penelitian hukum normatif, banyumedia publishing, malang 2006 hlm 57.
2. Kewajiban alimentasi

Oleh karena setelah dilakukanya pengangkatan anak si anak tersebut tinggal untuk diasuh dan dipelihara oleh orang tua angkatnya dan berada di dalam kekuasaan orang tua angkatnya, maka kewajiban alimentasinya antara anak dengan orang tua kandungnya beralih kepada orang tua angkatnya.

3. Pewarisan

Dalam masalah pewarisan bagi anak angkat, biasanya tergantung pada ketentuan hukum dimana para pihak dalam pengangkatan anak tersebut menundukan diri karena di Indonesia sendiri belum ada ketentuan perundangundangan yang mengatur tersebut.

Mengenai status atau kedudukan anak angkat, hakim mengatakan bahwa hal tersebut tergantung pada motivasi dan tujuan dilakukannya pengangkatan anak, adat istiadat yang belaku dan juga agama yang dianut oleh para pihak dalam pengangkatan anak. Berdasarkan keterangan yang berhasil di dapatkan, maka dengan disahkanya pengangkatan anak melalui penetapan pengadilan tidak berarti anak tersebut berkedudukan sebagai penerus keturunan dari orang tua angkatnya.

Apabila dalam pelaksanaannya pengangkat anak tersebut menimbulkan akibat sebagai berikut : 
1. anak angkat menggunakan nama keluarga dari orang tua angkatnya.

2. anak angkat dianggap sebagai anak kandung dan orang tua angkatnya dan berkedudukan sebagai ahli waris dan orang tua angkatnya.

3. hubungan perdata antara anak angkat dengan orang tua kandungnya putus sama sekali.

Maka pengangkatan anak tersebut cenderung tunduk pada hukum perdata barat.

Berkaitan dengan hal tersebut maka, pengangkatan anak merupakan salah satu dari peristiwa penting untuk dicatat dalam register pencatatan sipil. Yang dimaksudkan dengan Peristiwa Penting menurut pasal 1 angka 17 Undang-undang RI Nomor 23 tahun 2006 tentang administrasi kependudukan adalah kejadian yang dialami oleh seseorang, kelahiran, kematian, lahir mati, perceraian, pengakuan anak, pengesahan anak, pengangkatan anak, perubahan nama dan perubahan status kewarganegaraan. Sedangkan pasal 1 ayat 7 memberikan pengertian bahwa yang dimaksud Instansi Pelaksana adalah perangkat kabupaten/kota yang bertanggung jawab dan berwenang dalam urusan Administrasi Kependudukan. Pengertian Pencatatan Sipil menurut pasal 1 angka 15 adalah : pencatatan peristiwa penting yang dialami oleh seseorang dalam register catatan sipil oleh unit kerja yang mengelola pendaftaran penduduk dan pencatatan sipil. Khusus menyangkut pencatatan pengangkatan anak, harus dibuktikan dengan salinan persetujuan dari pengadilan negeri yaitu penetapan pengadilan (khusus bagi non muslim) dan Penetapan Pengadilan Agama (khusus bagi yang muslim).

Sebagai dasar untuk dibuat catatan pinggir pada kutipan akta kelahiran anak angkat tersebut. Dengan demikian anak angkat tidak memiliki dua kutipan akta kelahiran, tetapi hanya satu dengan tambahan catatan pinggir yang merupakan catatan mengenai perubahan status atas terjadinya peristiwa penting dalam bentuk catatan yang diletakkan pada bagian pinggir akta atau pada bagian akta yang memungkinkan (dihalaman/bagian muka atau belakang akta) oleh Pejabat Pencatat Sipil. Pemerintah juga bertanggung jawab dalam perlindungan terhadap hak anak angkat melalui Pencatatan pengangkatan anak. Orang tua angkat diharapkan mencatatkan pengangkatan anak, yang sudah mendapatkan penetapan pengadilan, yang kemudian dalam dimensi pencatatan sipil berupa pembuatan catatan pinggir di Kutipan Akta Kelahiran. Catatan pinggir pada kutipan akta kelahiran merupakan bukti legal bagi status perdata anak angkat. Diharapkan pemerintah dapat mengimplementasikan pemberlakuan Undang-undang Nomor 23 tahun 2006 tentang Administrasi Kependudukan dan 
Jurnal Independent Fakultas Hukum

Peraturan Pemerintah Republik Indonesia Nomor 54 tahun 2007 tentang Pengangkatan Anak.

Untuk memberikan perlindungan bagi anak angkat dalam penelitian ini adalah dengan melakukan pengangkatan anak melalui lembaga pengadilan untuk memperoleh kepastian hukum, keadilan, legalitas dan juga dokumen hukum. Dokumen inilah yang akan menyatakan bahwa telah terjadi pengangkatan anak secara legal.

\section{KESIMPULAN}

Perlindungan hukum bagi anak angkat tidak dapat diberikan karena tidak terdapat penetapan pengadilan yang menjadi dasar bahwa pengangkatan anak telah dilakukan dan sah menurut hukum. Maka penting adanya penetapan dari pengadilan, karena dengan begitu anak angkat akan mendapatkan dokumen hukum berupa penetapan pengadilan yang akan menguatkan serta untuk mendapatkan perlindungan hukum dari pemerintah apabila suatu saat terjadi masalah hukum. Dalam hal ini pemerintah juga berperan penting demi tegaknya hukum mengenai pengangkatan anak agar hak-hak anak angkat menjadi terlindungi dengan adanya penetapan dari pengadilan.

\section{DAFTAR BACAAN}

Fauzan, Hukum Pengangkatan anak, Kencana,2008,Jakarta

Jhony ibrahim, teori dan metode penelitian hukum normatif, banyumedia publishing, malang 2006

M. Budiarto, S,H, 1991, Pengangkatan Anak Ditinjau dari segi hukum, Akapres, jakarta

Zaini Muderis, Adopsi suatu tinjauan dari tiga sistem hukum, bina aksara, 1985, jakarta 